Acta regionalia et environmentalica 1

Nitra, Slovaca Universitas Agriculturae Nitriae, 2013, p. 19-25

\title{
THEORETICAL ARGUMENTS FOR CREATIVE ECONOMY IN POLICY-MAKING OF GOVERNMENTS AND PRACTICAL INTRODUCTION TO CREATIVE ECONOMY RESEARCH IN SLOVAKIA
}

\author{
Dana BAJUSOVÁ, Mária ŠPESOVÁ, Elena ŽÁRSKA \\ University of Economics in Bratislava, Slovak Republic
}

\begin{abstract}
Creativity is a new paradigm of development, which connects society in its economic, cultural, technological and social aspects at the macro and also micro level. Creativity, knowledge and access to information are central points of this paradigm and are considered to be engines of economic growth in globalizing world (UNCTAD, 2008). The paper offers a theoretical review of the concept and its tools and approaches, which are connected to creative economy. The paper maps the current situation of supporting creative economy in Slovakia at all levels of government. By analysis of strategic documents at national, regional and local level, we found out that promotion of creative economy is reflected only in a minority of received documents. The direct support of the creative economy was found only in documents of two county seats and one autonomous region. Any concrete concept was not adopted for supporting creative industries at the national level. Slovakia is just at the beginning in finding out how such industries contribute to the economy.
\end{abstract}

Keywords: creative economy, creative class, local development, small and medium sized cities, creativity supporting policy

The generally accepted fact is the ongoing process of transition from the industrial economy to the economy based on using qualitatively new information, creative knowledge and skills. Currently, it is necessary to add also human creativity which creates new services, knowledge and innovations to the traditional driving forces of economic, social and cultural development. The creative economy, considered as current global trend or paradigm, is influencing the further development of society. The pivotal items of this new paradigm are creativity, knowledge and access to information which are also powerful engines of economic growth in the globalizing world (UNCTAD, 2008). Ochrana (2010) emphasizes the necessity of examining the creative economy and developing appropriate strategies and policies to support it. That means, to implement such policy instruments and tools on each level of government that help to develop creativity, stimulate the growth of creative industries and create the best environment for the creative class in order to achieve and maintain economic growth. The content of the policy should be suitably selected and specified for each level of government. The concept of creative economy puts the attention on new categories such as creative industries and creative class. They are also associated with place as a creative space. The presence of creative industries and creative class in the structure of local (urban) economy has an impact on competitiveness of cities and dynamics of their growth, which are ambitions of each local unit.

\section{Methods}

The importance of supporting creative economy is documented by the European Union as well as many other foreign and international institutions which are interested in it. Numbers of authors research the basic categories of creative economy such as creative industry, creative class, and creative city. The necessity of their implementation to real economy is an important input for creating new strategic documents at each level of government.

Therefore, the aim of the paper is mapping of the current situation in promoting creative economy; which means, to examine the strategic documents of governments in Slovakia (at national, regional and local level) for presence of the ideas concerning support for the creative economy. To reach this goal, we used the method of analysis and comparison of selected tools, especially strategic documents (programme of economic and social development - PHSR), regulations (especially local regulations - generally binding regulations - VZN) and grant schemes of 8 county seats.

Since the creative economy is relatively unknown in Slovakia, in the first part of the paper we focus mainly on theoretical processing with current discussions on this phenomenon abroad. The theoretical examination of the current research in this field gives the foundation to further practical research, and this is the main reason for the substantial theoretical focus of this paper. The approaches investigate mainly local governments which are the object of our interest in this paper.

For the local level, there are several approaches or concepts which emphasize the support of creative economy. Those concepts are summarized in the first part of the paper, in which the analyses of theoretical approaches and assessment of documents and tools of local policy (policies of the cities) are applied.

\section{Results and discussion}

\section{Creative economy approaches - foreign experiences, measures and tools}

Ignoring the trend of creative economy by various actors would bring the risk for the European Union (EU) and its 
countries' economies to become passive players in the'arena' of international competitiveness. The leaders of EU are also aware of this fact, therefore the Green Paper (2010) - Unlocking the potential of cultural and creative industries - was created at the EU level. This European initiative increases the added value in supporting new global trend. Creating the right conditions is essential to the development of creativity and innovation; that is why there is used holistic and intersectional approach in the paper. The aim of the Green Paper is to stimulate discussion about requirements for creating the best environment for cultural and creative industries in the EU.

The document identifies the tasks that need to be discussed to ensure the development of cultural and creative industries. It is necessary to establish measures for enhancing the ability to experiment, to innovate businesses and provide easier access for funding. The support of creative economy has two dimensions. On the one hand, it is necessary to support this industry in its local environment; on the other hand, this support has also indirect effects on a wider range of economic and social areas.

The measures set out in the Green Paper, which should support the cultural and creative industries include: to strengthen support for researching creativity, to promote stronger, more systematic and extensive cooperation between the arts, academic and research institutions as well as public-private initiatives supporting the artistic experiments, to amplify the debate about creation a common space for the various elements at all levels, including the EU level, in which the parties can work together on specific actions in several areas of strategic interests. This involves building meeting places and 'laboratories' for innovation and experimentation that would allow collaboration in various disciplines, encouraging the creation of 'clusters of cultural and creative industries' ${ }^{\prime \prime}$, supporting intermediaries across sectors and disciplines. To the measures mentioned above should also be classified the issues relating to setting up a business together with the possibilities of financing and promoting best practices in the field of accounting and transparency and facilitating the bureaucracy for such companies.

In the Green Paper there is stressed that the development of cultural and creative industries progresses especially at the local and regional level, where it plays an important role in their development, same as in global meaning. Successful media to long term strategies are based on a combination of investment to infrastructure and human capital, focusing on investments to areas which are key for cultural and creative industries ${ }^{2}$ (such as new business models, creativity

1 Functional clusters are based on an intensive cooperation between the various interconnected innovation actors and institutions.

2 To such industries is included: the promotion of cultural heritage for commercial purposes, development of infrastructure and services in the field of culture in order to promote sustainable tourism, creating clusters of local businesses and partnerships between cultural and creative industries and industry, research, education and other sectors, establishing innovation labs, to develop cross-border strategies for integrated management of natural and cultural resources and boost local economies, sustainable urban development and innovations, digitization, improving skills and human capital, creative partnerships with other sectors).

The importance of this theme is also given by the fact that more and more government officials at the national level are dealing with the status and the development of creative industries. The result is an adoption of various concepts for the development and promotion of these industries. Ministry of Culture, Media and Sport in the United Kingdom (UK) sensed new trends among first and in 1998 issued a document which mapped the creative industries in the UK (Creative Industries Mapping Document - CIMD, 1998, 2001). It was the paper that first presented a comprehensive analysis of the economic contribution of creative activities. To the creative industries were included "those industries which have their origin in individual creativity, skill and talent and which have a potential for wealth creation and job creation through the generation and utilizing of intellectual property." (CIMD, 1998). Such definition links the creative industries with the sector of traditional areas, which are arts and crafts.

Later in 2001, another survey of creative industries was released, but already with more reliable data. The document confirmed the fact that the concept of creative industries had become a widely used and accepted. An important position of such industries was also attributed to the knowledge economy - a force for economic growth. The document revealed the general problems affecting the creative industries, which included the areas of education, financing of creative enterprises, the area of intellectual property protection and export promotion.

New structure of the policy was defined in the years 1997-2001 in the UK. This policy should have allowed the growth of creative and cultural sectors. This was the birth of creative industries 'experiment'. In the years 2001-2005, the theory of creative industries was tested and observed on real and concrete initiatives at the local level. In those years there was a significant increase of creative industries support projects and also a variety of on-creativity-oriented institutions, associations and organizations had been established in the UK.

The British Department was not the only one that has undertaken the definition of creative industries, there were other institutions such as WIPO ${ }^{3}$, UNCTAD, UNESCO, and authors such as Howkins (2007), Potts and Cunningham (2008) and Boix et al. (2010). There are studies (e.g. KEA, $2010 \mathrm{a}, 2010 \mathrm{~b}^{4}$ ) that examine the mechanisms promoting cultural and creative industries; they also identified a number of tools used in different countries, for example: tools for attracting private investments by reducing risk (suitable for capital-intensive sectors - the use of tax credits), guarantee arrangements in respect of loans granted by banks to ensure compliance in entering the market, the use of specific funding mechanisms - creation of specialized banks, a special fund for venture capital or direct subsidies,

3 World Intellectual Property Organization

4 The titles of studies: Business Innovation Support Services for Creative Industries. (2010a); Promoting Investment in the Cultural and creative Sector: Financing Needs, Trends and Opportunities. (2010b). 
Table 1 Selected documents dealing with policies supporting the creative economy

\begin{tabular}{|c|c|}
\hline Organization/document & Discussed field \\
\hline $\begin{array}{l}\text { European Union: Green Paper - Unlocking } \\
\text { the potential of cultural and creative } \\
\text { industries }\end{array}$ & $\begin{array}{l}\text { - the aim is to stimulate discussion of requirements for creating the best environment } \\
\text { for cultural and creative industries in the EU. The document identifies the tasks that } \\
\text { need to be discussed to ensure the development of cultural and creative industries. }\end{array}$ \\
\hline $\begin{array}{l}\text { KEA: Business Innovation Support Services } \\
\text { for Creative Industries. }\end{array}$ & $\begin{array}{l}\text { - document provides background information and strategic advice regarding the } \\
\text { potential establishment of European initiative to promote innovative creative } \\
\text { industries throughout Europe. A specific focus rests on the provision of "Business } \\
\text { Innovation Services" and how policy intervention at the EU level could optimise } \\
\text { such services provided to creative companies and thereby promote the societal and } \\
\text { economic impacts of the creative industries. }\end{array}$ \\
\hline $\begin{array}{l}\text { KEA: Promoting Investment in the Cultural } \\
\text { and creative Sector: Financing Needs, Trends } \\
\text { and Opportunities. }\end{array}$ & $\begin{array}{l}\text { - it provides an analysis of the financing needs of the cultural and creative sector. It also } \\
\text { looks at the existing trends and identifies opportunities for improvements in access } \\
\text { to finance within the sector in some European countries. It aims to raise awareness } \\
\text { amongst policy makers of the financing schemes and support measures that can } \\
\text { enable the development of the cultural and creative industries }\end{array}$ \\
\hline $\begin{array}{l}\text { UNCTAD: Creative Economy: A Feasible } \\
\text { Development Option chapter 8: Policy } \\
\text { strategies for creative industries }\end{array}$ & $\begin{array}{l}\text { - in the paper there is discussed the role of policy at the national and international level } \\
\text { and also the main steps which need to be done. }\end{array}$ \\
\hline
\end{tabular}

provision of micro financing - providing micro loans and loans to provide general support and advice - creating clusters and incubators, private meetings with investors, providing training for management, export promotion etc.

Obviously some of these tools should be provided from the national level (e.g. to ensure compliance in entering the market, export promotion), others are more effective if they are provided and managed at the local level. Local officials have better preconditions to develop an appropriate strategy to reflect the real needs in the region (e.g. providing advice, training, micro-finance projects or businesses, the establishment of incubators, etc.). Cities can apply for development grants and tax breaks, loans and guarantees, equity financing, or non-financial support.

In the table 1, there is a review of selected documents dealing with this issue.

\section{Researching and supporting of creative economy at local level}

Local level plays an important role in development of the creative economy. In foreign literature we encounter concepts that summarize the approaches to its development. To this concepts could be included concepts of creative cities and 'creative ecosystem'.

The concept of creative cities constitutes to the newest concepts of urban growth. It emphasizes the importance of firms in creative industries and creative individuals for urban development (Rehák, 2012). Issues of, technology, research and development activities, big cities are currently of key importance in the global economy. The competition between them is increasing. .Ideas of creativity and creative potential in urbanism and city planning are applied. This creates a new paradigm of perception of the urban organism, its development, growth and success factors. ${ }^{5 \prime \prime}$

Costa (2007) summarizes the different approaches of the creative city concept into 3 groups:

5 In: Východiská koncepcie na podporu kultúrneho a kreatívneho priemyslu v Slovenskej republike, 2011
1. Creative city as a toolkit for urban development.

2. Creative city focusing on creative activities.

3. Creative city as the capacity to attract creative human resources.

One of the first authors of the creative city concept - Landry $(2008)^{6}$ - presents it as urban development tool. He elaborates it in his book The Creative City: A Toolkit for Urban Innovators, in which he highlights that development strategies of creative cities are different from city to city because it depends on their local culture and identity. Such strategies are also more focused on people since their creativity is the driver of urban development (Landry, 2008 , p. 160). Landry claims that cities should transform their planning policy of economic development to become creative, but the final aim is not to pursue the objective of promoting itself, but the achievement of economic goals. The core definition is "to find new solutions to quotidian problems" of cities. "Generating a creative milieu and discovering and keeping creative processes for urban management are the keys to success in a perspective centred on creativity as a toolkit for planning and innovating in cities" (Costa et al., 2007).

The second approach to creative activity is based on the definition of creative industries ${ }^{7}$. The starting point is the interrelatedness of cities and creative industries, which are generating products. Thus, a creative city is focused on promoting and creating so called cultural product. This approach is one of the most widespread, used and implemented in the policies of cities. Target points of support are creative cultural products and services. The emphasis is placed on drafting measures and creating favourable conditions for attracting and developing creative businesses as a source of job creation and wealth. These measures are based on the use of subsidies and tax breaks.

6 The concept of creative cities was defined by Landry in the late 80 's.

7 Creative Industries have been defined at first by Department of Culture, Media and Sport in the UK 
Table 2 The characteristics of strategic approaches to promote creative economy in small and medium-sized cities

\begin{tabular}{|l||l|}
\hline Strategic Approach & \multicolumn{1}{|c|}{ Characteristics } \\
\hline Physical approach & $\begin{array}{l}\text { - based on urban regeneration. The main objective is the creation of creative spaces to attract artists. This } \\
\text { proposed strategy often follows the creation of creative neighbourhoods of old and degraded areas. }\end{array}$ \\
\hline Green approach & $\begin{array}{l}\text { - in this strategy is used a set of natural and symbolic amenities and also its unique cultural facilities. The } \\
\text { aim of these strategies is to attract and retain artists and creative people. Very important factors are the } \\
\text { authenticity and identity of the territory. }\end{array}$ \\
\hline Thematic approach & $\begin{array}{l}\text { - the idea of this strategy is to select a specific segment of the cultural and creative industries and its } \\
\text { reflection in public policy (music, dance, theatre, food, etc.). }\end{array}$ \\
\hline Integrated approach & $\begin{array}{l}\text { - this strategy is built on attraction of talented people and creative industry businesses with the help of } \\
\text { integrated tools that have impact on the social, cultural and environment. }\end{array}$ \\
\hline
\end{tabular}

Source: Authors, according to INTELI, 2011

The last approach is based mainly on Florida's efforts. The best known is his book The Rise of the Creative Class where he defines the concept of creative class - highly skilled and innovative human resources. He states that cities themselves become competitors in the 'fight' for representatives of this class. Florida claims that they form the basis for competitiveness of the currently most dynamic contemporary urban areas. He links the idea to be creative and innovative with the ability to retain and attract new social classes equipped with knowledge and skills necessary for the creative sector which has a high share in the growth and competitiveness of the current economy. We can say, this is a process of improving the quality of jobs as a tool to attract talents which subsequently raise the investments into companies and new businesses, employment growth, income and innovation growth.

The theoretical concepts have a direct impact on public policies creation and the exploring of relationship between creativity and local development. In the creative class approach the emphasis is put into improving the quality of jobs as a tool to attract talents. On the other hand, the creative industry approach tells us to create favourable conditions for creative businesses, since they are a prerequisite for providing jobs and wealth growth in the locality.

The concept of 'creative ecosystem' (see Figure 1) is perceived as a creative environment based on assets that

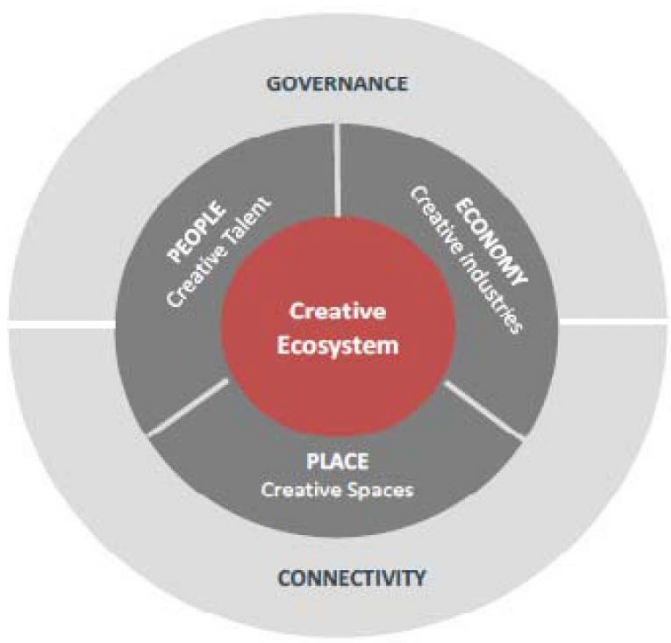

Figure 1 The Creative Ecosystem

Source: Creative-based Strategies in Small and Medium-sized Cities: Guidelines for local authorities. 2011. INTELI. p. 17 create socio-economic growth and development. It consists of three interrelated components: economy - creative industries, place - creative space and creative people - creative talent. This interaction is largely dependent on specific governance and institutional government structure, on their local hierarchy position, and on their access to information and communication technologies connectivity (INTELI, 2011).

In available academic studies or policy studies, this concept appears more in relation to the big and metropolitan cities and is often neglecting the importance and the role of small and medium-sized cities and regions. However, the INTELI study (2011) has examined the concept of creative ecosystem - its approach and tools - on the example of small and medium-sized cities. Based on the analysis of case studies of creative areas, 4 types of policy strategies have been identified to promote a new trend: the 'physical approach', 'green approach', 'thematic approach', and 'integrated approach'. These approaches are defined in the table 2 .

In reality, these strategies are not implemented separately; in fact, these strategies and their different instruments overlap each other. However, this systematic distinguishing of strategies is necessary to generate knowledge and information in the decision-making process.

It should be noted that there is no strategy that could be used as a pattern for other territories. In their determining and selecting it is important to relate on the initial (starting) position of the territory, its institutional organization and specific forms of governance used in this process. It is also necessary to emphasize the importance of historical tradition, the symbolic value of place and its cultural heritage. The strategy should connect tradition with innovation and the future with the past.

Creative economy of small and medium sized cities is increasingly studied by lots of authors, who seek to highlight the achievements of small communities through case studies. Research of this problem is incited also by the fact that approximately $40 \%$ of the EU population lives in small towns. We also observe a reverse flow migration from big cities to small towns mainly because of their natural and cultural capital and a higher quality of life.

Several models are examining the relationship between creativity and spatial development, which usually can be divided into two main approaches - exploring the creative industries approach and creative class approach. These 
approaches, however, are more suitable for examining large metropolitan cities and the creative economy in small or middle sized cities. Several studies show (e.g. Andersen, 2010) that it is not appropriate to use this approach in evaluation of small cities. When evaluating small and medium-sized cities it is necessary to take into account their specific features, e.g.: territorial capital, natural and cultural amenities, rural lifestyle and quality of life. Therefore, it is not appropriate to apply the approaches used for major cities in small ones, but public policies of the major cities should be adapted and based on conditions of the small ones $^{8}$ (Selada, 2011). Local authorities should think, plan and implement policies to promote creativity based on their own specificities, resources and preconditions.

We have to note that small cities play a role in the 'battle for the creative class.' The ability of small cities to attract the creative class depends largely on the use of their own advantages and the ability to provide a good quality of life. "Creative people look for alternative lifestyles to those prevalent in big cities, giving priority to well-being associated with sports, healthy food, preservation of the environment and sustainable practices, and to the sense of community and local authenticity" (Selada, 2011). Small cities in pursuance of their amenities (e.g. geographical location, tradition, natural resources, quality of life, etc.) attract the creative class. We distinguish between natural, cultural and 'symbolic' assets that are inimitable, hardly reproducible, and which contribute to the uniqueness of the place. Moreover, small towns offer better possibilities for community involvement, cooperation and participation in community affairs.

\section{Creative economy in Slovak conditions and its implications at local level}

Slovakia starts to do the first steps towards realizing the importance of the idea of creative economy in the policy making. At the national level, Slovakia has started to cooperate with the British Council on the project Creative and cultural industry economy of Slovakia. The Ministry of Culture of the Slovak Republic has created the document for the promotion of cultural and creative industries in Slovakia. The aim of the document should be to "create a basic ideological and legal framework - a premise for the future activities in defining the economic and legal status of the creative and cultural industries in Slovakia, in regard to fields such as copyright protection, creation of support programs and creative enterprises in the cultural and creative industries (Chudinová, 2011). Creativity support initiatives were also the keynote of the previous government. So far the only document constituting a background for the final intended document was approved (document is called: Východiská koncepcie na podporu kultúrneho a kreatívneho priemyslu v Slovenskej republike).

According to this document, for creating conditions for development of creative industries in the Slovak Republic it is necessary to invest in following public policy areas:

8 In examining relationship between small cities and creative economy we are facing new concepts such as 'creative countryside' or 'creative rural economy' political awareness, favourable conditions for development of creative industries, promotion of creative clusters, and support of links between creativity and innovation.

The document does not avoid the essential aspects of the new programming period, the framework of intellectual property rights and issues of co-regulation. It considers the EU structural funds as important financial resources that provide a structured inter-sector approach within the programming documents. These funds also enable the implementation of the already mentioned tools for developing of the creative industries.

It should also focus on effective implementation of legislation and practice. The document points out the necessity of creating judicial proceedings in matters of intellectual property rights. The concept of co-regulation allows the state to intervene if self-regulatory mechanisms fail. Such proceedings should lead to a better development of creative industries. A relevant question of correct relations between central and local government comes out. We should not forget the role of cities in supporting the development of creative industries and creative economy. Their representatives should put their attention to the economic, social, environmental and cultural development of cities. Other issues that should be included in development papers at regional and local level are: improving the environment for business, providing lifelong learning, encouraging innovation and entrepreneurship, culture preservation, promotion of local characteristics, the balance of entrepreneurship and environment space for residents.

At the regional level in the Slovak Republic the issue of creative economy is mentioned only in strategic documents of the Košice region. They also contain a document especially devised for the strategy of implementing the concepts of creative industry and creative economy in the public policy. This document reveals us that this region has a full awareness of the development potential (in employment rate, competitiveness and attractiveness of the Košice region) of the idea of creative economy. The strategy of the document is based on the following 5 pillars:

1. Infrastructure of creative economy.

2. The creative economy information system.

3. Human resources and employment development.

4. Marketing, promotion and information dissemination.

5. Cooperation and networking.

The aim of the concept is, according to the proposed measures and activities in these areas (pillars), to contribute to the dynamic development of the creative economy and creative cities in the Košice region.

The document declares an effort to boost cooperation between different actors of the creative economy in the Košice region and providing quality services to strengthen the creative economy, especially in cooperation with organizations founded by its regional self-government. Similar activities have not appeared in other self-governing regions of Slovakia yet.

At the local level we have observed the implementing of creative cities and creative economy concepts in 8 county seats, which are the biggest cities in the Slovak Republic. Only the biggest of them - Bratislava $(413,192)$ and Košice 
$(240,688)$ - unlike the others, have incorporated concepts of creative economy and creative industries into their plans of economic and social development (strategic plans of cities). Bratislava is aware of the creativity as a potential source of development which is mentioned in its document. It also shows the need for greater awareness of creative use of knowledge in development. In the field of knowledge economy, we find the priority entitled "Profiling Bratislava as a City of culture and creative industries". The measures (6) of this objective have a broad spectrum - ranging from promoting the introduction of creative industry supporting tools, through direct support of the arts and specific projects, to supporting the infrastructure (galleries, cultural centres, film clubs, etc.) but also to mention the role of popularizing and promoting the development of IT sector (attracting development activities of foreign companies, competition for young developers to support schools in the field of IT). ${ }^{9}$

In the strategic document of Košice we can read that "cultural and creative industries are an important part of the economy"10. But the implementation of the idea of creative economy into the strategic plan in Košice has his reason Košice applied for the title of European Capital of Culture ${ }^{11}$ for the year 2013. Košice applied for this title by realizing the project INTERFACE 2013. The mentioned project as well the event European Capital of Culture is driven by the theory of the creative class from Richard Florida which says that one of the main city objectives should be generating, attracting and retaining creative and innovative talent. Košice therefore chose a way to promote creativity, talent, knowledge, but also to regenerate public spaces and try to make it useable by citizens. For this title applied also the city of Prešov. And before the award was granted to the winner, Košice and Prešov signed a Memorandum of bilateral cooperation in preparing for the future events. Such cooperation should have an impact of both regions - Košice region and Prešov region. Despite such cooperation and involvement of Prešov in preparing the event European Capital of Culture, there is surprisingly no mention about the concepts of creative economy, creative industries or creative city in its strategic documents.

All other regional cities are supporting various cultural events (e.g. through grants) but without pursuing economic aspects of building a creative city or the promotion of creative industries. Thus, the documents of these cities are lacking the awareness of the importance of incorporating the above mentioned terms. On the other hand, more and more discussions about the topic of creative economy are recognized in various organizations, associations and agencies dealing with culture. This indicates that from the spatial aspect, cities are the places where creativity is being discussed, but the self-governments themselves do not demonstrate the interest of incorporating the issues in

9 Program hospodárskeho a sociálneho rozvoja hlavného mesta SR Bratislavy na roky 2010 - 2020)

10 Program hospodárskeho a sociálneho rozvoja mesta Košice na roky $2009-2015$

11 The title European Capital of Culture is awarded by the European Commission and European Parliament since 1985 their policies. This indicates that they do not recognize the positive effects of such policies.

\section{Conclusion}

This paper discusses the approaches and tools that are used in the implementation of policies promoting the creative economy. More and more attention is given to the issues of creative economy; defining new categories such as creative industries and creative class. They are also associated with the place as a creative space. The presence of creative industries and creative class in the structure of local (urban) economy has an impact on the competitiveness of cities. Increasing competitiveness is the ambition of every local unit. A city is perceived as a space for creating an environment that can absorb and attract creative industries, and representatives of the creative class as the important elements of urban development. Creating favourable conditions is essential to its development. Several documents give importance to the local levels, which play a key role in the development of creative economy. In this paper we identified the tools and concepts that characterize approaches to urban development with a view of promotion of the creativity as a stimulus of local development.

The subject of our interest was mapping of the current situation in Slovakia in promoting creative economy. Based on the analysis of strategic documents at various levels, we found out that Slovakia is just at the beginning of putting the idea into the policy-making process. This statement is also supported by the fact that only 2 of 8 county seats mentioned the concept of creativity in their strategic documents. On the other hand, at the national level there are only fragments of creative economy ideas put into the documents. The same applies to the governments of regional level where only a little attention is given to the concept of the creative economy, too.

The fact that creative industries are becoming an integral part of the economy remains valid. Therefore, it is necessary to pay attention to them; to create favourable preconditions and remove obstacles and make decisions that will facilitate their further development. This is the role of the representatives of our cities, regions and state.

"This paper was supported by the Slovak Research and Development Agency under the contract No. APVV-0101-10".

\section{References}

ANDERSEN, K. V. - HANSEN, H. K. - ISAKSEN, A. - RAUNIO, M. 2010. Nordic city regions in the creative class debate: putting the creative class thesis to a test. In: Industry and Innovation, vol. 17, 2010, no. 2, p. 215-240. ISSN 1469-8390.

BOIX, R. - LAZZARETTI, L. - CAPONE, F. - DE PROPRIS, L. - SÁNCHEZ, D. 2010. The geography of creative industries in Europe: Comparing France, Great Britain, Italy and Spain. $50^{\text {th }}$ Anniversary European Congress of the Regional Science Association International: "Sustainable Regional Growth and Development in the Creative Knowledge Economy“. Jönköping, 2010.

BUSINESS INNOVATION Support Services for Creative Industries. 2010a. [online]. KEA - European Affairs, Feb 2010 [quote. 201201-10]. Available at: <http://www.europe-innova.eu/c/document_library/get_file?folderld=182854\&name=DLFE-8916.pdf $>$ 
CHOVANEC, M. 2012. Kreatívna ekonomika: Priestorové aspekty lokalizácie kreatívnych odvetví v Slovenskej republike. Bratislava : NHF EUBA, 2012. 125 p. Dissertation thesis.

CHRISTOPHERSON, S. 2004. Creative Economy Strategies for Small and Medium Size Cities: Options for New York State, Revised version of paper prepared for the Quality Communities Marketing and Economic Workshop, Albany New York, 2004, [online]. [quote 2012-01-10] Available at: <http://www.community-wealth.org/_ pdfs/articles-publications/anchors/paper-christopherson.pdf>

CHUDINOVÁ, E. 2011. Kreatívny priemysel. [online]. Ministerstvo kultúry Slovenskej republiky. 25.3.2011 [quote 2012-01-10]. Available at: <http://www.culture.gov.sk/aktuality/kreativny-priemysel> COMUNIAN, R. 2010. Rethinking the Creative City: The role of Complexity, Networks and Interactions in the Urban Creative Economy, [online]. Urban Studies, September 2010. [quote 2012-0110] Available at: <http://usj.sagepub.com/content/48/6/1157>

CORLESS, J. 2012. Creative Revolution: How British Creative Industry Policy is Changing the World. [online]. Creative Revolution. [quote 2012-01-10] Available at: <http://theideafeed.com/ creative_economy/>

COSTA, P. et al. 2007. A discussion on the governance of 'Creative Cities': Some insights for policy action. In: Norsk Geografisk Tidsskrift - Norwegian Journal of Geography, 2007, no. 61, p. 122132. ISSN 0029-1951

CREATIVE ECONOMY. Report 2010. [online]. UNCTAD: United Nations Conference on Trade and Development. 15th December 2010. [quote 2013-25-04]. Available at: <http://unctad.org/es/ Docs/ditctab20103_en.pdf>

CREATIVE INDUSTRIES Mapping Document, 1998, Department of Culture, Media and Sport, United Kingdom. 1st January, 1998 [quote. 2012-01-10]. Available at: <http://webarchive.nationalarchives.gov.uk/+/http://www.culture.gov.uk/reference_library/ publications/4740.aspx>

CREATIVE INDUSTRIES Mapping Document, 2001, Department of Culture, Media and Sport, United Kingdom. 26th January 2001 [quote. 2012-01-10]. Available at: http://webarchive.nationalarchives.gov.uk/+/http://www.culture.gov.uk/reference_library/ publications/4632.aspx/>

CREATIVE INDUSTRIES. [online]. WIPO: World Intellectual Property Organization. [quote 2013-25-04]. Available at: <http://www. wipo.int/ip-development/en/creative_industry/>

CREATIVE-BASED Strategies in Small and Medium-sized Cities: Guidelines for local authorities. 2011. [online]. INTELI: Inteligência em Inovação, Centro de Inovação June 2011. [quote 2012-01-10]. Available at: $<$ http://urbact.eu/fileadmin/Projects/Creative_Clusters/documents_media/URBACTCreativeClusters_TAP_INTELI_Final.pdf $>$

FLORIDA, R. 2002. The Rise of the Creative Class: And how it's Transforming Work, Leisure and everyday Life. New York : Basic Books, 424 p. ISBN-13: 978-1864032567

GREEN PAPER - Unlocking the potential of cultural and creative industries. [online]. European Commission. [quote 201201-10]. Available at: <http://ec.europa.eu/culture/documents/ greenpaper_creative_industries_en.pdf $>$

HOWKINS, J. 2007. The Creative Economy: How People Make Money from Ideas. London : Penguin Books. 288 p. ISBN-13: 978-0140287943

IVANIČKOVÁ, A. 2012. Kreativita ako hnacia sila rozvoja stredných a malých miest. Working papers, version 1.1. Bratislava: KRENAR, 2012. JOMBÍK, V. 2011. Vláda má kreatívnemu priemyslu vytvorit’ podmienky. [online]. Stratégie ONLINE. Hospodárske noviny. 31. 5. 2011. [quote 2012-01-10]. Available at: <http://strategie.hnonline.sk/sk/sedy/rozhovor_mesiaca/vlada-ma-kreativnemu-priemyslu-vytvorit-podmienky.html>
KLOUDOVÁ, J. a i. 2010a. Kreativní ekonomika - vybrané ekonomické, právní, masmediální a informační aspekty. 1. vyd. Bratislava : EUROKÓDEX, s. r. o., 2010. 216 s. ISBN 978-80-89447-20-6

KONCEPCIA ROZVOJA kreatívnej ekonomiky KSK. 2011. [online]. Košický samosprávny kraj. September 2011 [quote 201201-10]. Available at: <http://zastupitelstvo.vucke.sk/Dokumenty/2011/09-2011/dokument1964\%20vo3zast09bod15-4main.pdf> LANDRY, Ch. 2008. The Creative City: A Toolkit for Urban Innovators. Earthscan Publications Ltd., 2008. 350 p. ISBN-13: 978-1844075980

OCHRANA, F. 2010. Efektivní a účinná veřejná správa. Smart Administration v podmínkách kreativní ekonomiky. In: KLOUDOVÁ, J. et al. 2010b. Kreativní ekonomika - trendy, výzvy, př́iležitosti. Prague : GRADA Publishing, a. s., 2010. 224 s. ISBN 978-80-247-3608-2.

POTTS, J. - CUNNINGHAM, S. 2008: Four models of the Creative Industries. In: International Journal of Cultural Policy, vol. 14, 2008, no. 3. ISSN 1477-2833

PROGRAM HOSPODÁRSKEHO a sociálneho rozvoja hlavného mesta SR Bratislavy na roky 2010-2020. [online]. [quote 2012-0226] <http://www.bratislava.sk/VismoOnline_ActionScripts/File. aspx?id_org=700000\&id_dokumenty=11025702>

PROGRAM HOSPODÁRSKEHO a sociálneho rozvoja mesta Košice 2009-2015. [online]. [quote 2012-02-26] <http://www.kosice. sk/static/prilohy/phsr/Politika_a_strategia_rozvoja_mesta_Kosice_2008-2015.pdf>

PROMOTING INVESTMENT in the Cultural and creative Sector: Financing Needs, Trends and Opportunities. 2010b. [online]. KEA - European Affairs, May 2010 [quote 2012-01-10]. Available at: <http://www.keanet.eu/docs/access\%20to\%20finance $\% 20$ study_final\%20report_kea\%20june2010.pdf>

REHÁK, Š. 2012. Kreatívne mestá. Teoretický koncept a jeho kritické zhodnotenie. Working papers, final version. Bratislava : KRENAR, 2012.

SELADA, C. - VILHENA DA CUNHA, I. - TOMAZ, E. 2011. Creative-based strategies in small cities: A case-study approach. 2011. [online] REDIGE. [quote 2012-06-20]. Available at: <http://www.inteli.pt/ uploads/documentos/documento_1328780477_7142.pdf>

UNCTAD. 2008. Creative Economy Report 2008: The Challenge of Assessing the Creative Economy towards Informed Policy-making. [online]. United Nations Conference on Trade and Development. [quote 2012-01-10] Available at: <http://www.unctad.org/ creative-economy>

VÝCHODISKÁ KONCEPCIE na podporu kultúrneho a kreatívneho priemyslu v Slovenskej republike. [online]. 81. SR Government meeting $14^{\text {th }}$ December 2011. [quote 2012-01-10]. Available at: $<\mathrm{http}: / /$ www.1snsc.sk/Navrh_materialu_o_podpore_kulturneho_a_kreativneho_priemyslu_v_SR_odoslany_na_rokovanie_vlady_SR>

WAITT, G. - GIBSON, CH. 2009. Creative Small Cities: Rethinking the Creative Economy in Place. In:Urban Studies, vol. 46, 2009, no. 5-6. ISSN 1223-1246

\section{Contact address:}

Dana Bajusová, Mária Špesová, Elena Žárska, University of Economics in Bratislava, Faculty of National Economy, Department of Public Administration and Regional Development 